\title{
Sedimentary characteristics and processes of the Paleogene Dainan Formation in the Gaoyou Depression, North Jiangsu Basin, eastern China
}

\author{
Xia Zhang ${ }^{1} \cdot$ Chun-Ming Lin $^{1} \cdot$ Yong Yin $^{2} \cdot$ Ni Zhang ${ }^{1} \cdot$ Jian Zhou $^{1} \cdot$ \\ Yu-Rui Liu ${ }^{3}$
}

Received: 31 January 2016/Published online: 30 July 2016

(c) The Author(s) 2016. This article is published with open access at Springerlink.com

\begin{abstract}
In this paper, the type, vertical evolution, and distribution pattern of sedimentary facies of the Paleogene Dainan Formation in the Gaoyou Depression of the North Jiangsu Basin are studied in detail. Results show that fan delta, delta, nearshore subaqueous fan, and lacustrine facies developed during the Dainan Formation period and their distribution pattern was mainly controlled by tectonics and paleogeography. The fan delta and nearshore subaqueous fan facies predominantly occur in the southern steep slope region where fault-induced subsidence is thought to have created substantial accommodation, whereas the delta facies are distributed on the northern gentle slope which is thought to have experienced less subsidence. Finally, the lacustrine facies is shown to have developed in the center of the depression, as well as on the flanks of the fan delta, delta, and nearshore subaqueous fan facies. Vertically, the Dainan Formation represents an integrated transgressiveregressive cycle, with the $\mathrm{E}_{2} d_{1}$ being the transgressive sequence and the $\mathrm{E}_{2} d_{2}$ being the regressive sequence. This distribution model of sedimentary facies plays an important role in predicting favorable reservoir belts for the Dainan Formation in the Gaoyou Depression and similar areas. In the Gaoyou Depression, sandstones of the subaqueous
\end{abstract}

Chun-Ming Lin

cmlin@nju.edu.cn

1 State Key Laboratory for Mineral Deposits Research, School of Earth Sciences and Engineering, Nanjing University, Nanjing 210023, Jiangsu, China

2 School of Geographic and Oceanographic Sciences, Nanjing University, Nanjing 210023, Jiangsu, China

3 Institute of Geological Sciences, Jiangsu Oilfield Branch Company, SINOPEC, Yangzhou 225009, Jiangsu, China

Edited by Jie Hao distributary channels in the fan delta and the subaqueous branch channels in the delta are characterized by physical properties favorable for reservoir formation.

Keywords Sedimentary facies - Distribution pattern · Sedimentary evolution - Dainan Formation - Gaoyou Depression · North Jiangsu Basin

\section{Introduction}

Lacustrine rift basins are distributed widely in eastern China. About 300 Mesozoic-Cenozoic rift basins cover a total area of approximately $2 \times 10^{6} \mathrm{~km}^{2}$. These depressions occur as one of the most important petroliferous basin types in China, and have therefore been the focus of exploration for subtle reservoirs (Xian et al. 2007; Wang et al. 2014; Jiang et al. 2014). The sedimentary systems developed in these rift basins in eastern China, such as the Bohai Bay Basin, the southern part of the North China Basin, the Erlian Basin, and the Ural Basin, tend to form favorable lithologic or structural-lithologic reservoirs, even in the conglomerates and/or sandy conglomerates of the nearshore subaqueous fans that they host (Sui 2003; Zhao et al. 2011; Cao et al. 2014; Zhang et al. 2014a). The North Jiangsu Basin is one of the richest regions for oil and gas in eastern China, given its thick and wide distribution of Mesozoic-Cenozoic strata. The Paleogene Dainan Formation is one of the most productive reservoir intervals in the Gaoyou Depression, North Jiangsu Basin (Qiu et al. 2006). The production of most major oil fields in the Dainan Formation is now in decline; thus, a precise description of the sedimentary facies of these reservoir sandstones is greatly needed. To date, studies of the Dainan Formation have focused primarily on the paleontological, sequence stratigraphic, and structural 
compartmentalization of the basin (Dong 1999; Lu 2000; Zhang et al. 2005; Pang and Cao 2005; Zhu et al. 2013; Chen et al. 2015). There have also been studies of the sedimentology (Chen and Wu 2006; Zhang et al. 2007; Xia et al. 2008; Ji et al. 2012; Zhao et al. 2015) and provenance (Zhou et al. 2010; Zhang et al. 2014b) of the basin fill. However, the regional distribution pattern and processes of sedimentary facies have yet to be understood at a sufficiently high temporal and spatial resolution. Such detail is crucial for reliable predictions of depression-scale sedimentary architecture within and/or between individual oil fields. The objectives of this study are to (1) describe the characteristics, spatial distribution, and evolution processes of sedimentary facies of the Dainan Formation, and (2) reconstruct the sedimentary system and model of the Gaoyou Depression, which may have broad implications for other similar rift basins.

\section{Geological setting}

The North Jiangsu Basin is a large Mesozoic-Cenozoic fault-depressed basin with the basement being composed of Proterozoic metamorphic rock and Early Mesozoic carbonate, turbidite, and clastic rocks (Shu et al. 2005). It is located east of the Lower Yangtze Plate covering an area of approximately $35 \times 10^{3} \mathrm{~km}^{2}$ (Fig. 1a), and it can be divided into four east-westward oriented tectonic units: the Dongtai Depression, Jianhu Uplift, Yanfu Depression, and the Binhai Uplift (Qiu et al. 2006; Fig. 1b).

The Gaoyou Depression is located in the central Dongtai Depression with an area of about $2.7 \times 10^{3} \mathrm{~km}^{2}$. It is characteristic of a dustpan-like depression (Chen 2001; Zeng 2007; Zhu et al. 2013; Fig. 1c, d) resulting from the differential subsidence of fault blocks during the Yizheng Movement in the Late Cretaceous and the Wubao Movement in the Late Paleocene (Chen 2001). The Gaoyou Depression is bounded to the south by the Zhenwu fault belt (separating it from the Tongyang uplift), and links to the Zheduo low uplift through a slope in the north (Fig. 1c). The western and eastern boundaries are the Lingtangqiao low uplift and the Wubao low uplift, respectively (Fig. 1c). Due to the influence of Indian and Pacific plate movements, there are three groups of fractures (ENE, NE, and NW orientations) developed in the Gaoyou Depression, with those oriented ENE dominant. These ENE faults (Zhen 1, Zhen 2, and Hanliu faults) separate the Gaoyou Depression into three ENE trending sections from south to north: southern step-fault zone, central deep depression zone, and northern slope zone (Qiu et al. 2006; Chen 2001; Fig. 1c). The central deep depression zone can be further divided into three subdepressions from west to east: Shaobo, Fanchuan, and Liuwushe (Fig. 1e).
The Mesozoic-Cenozoic sedimentary thickness in the Gaoyou Depression can reach up to $7000 \mathrm{~m}$. Of this, the Dainan Formation $\left(\mathrm{E}_{2} d\right)$ has a thickness of approximately $1500 \mathrm{~m}$ and has been one of the most productive reservoir intervals in the Gaoyou Depression over the last 30 years, hosting over 15 oil-gas fields containing about $4.1 \times 10^{8}$ tons of recoverable oil. The $\mathrm{E}_{2} d$ lies between the overlying Funing Formation $\left(\mathrm{E}_{1} f\right)$ and the underlying Sanduo Formation $\left(\mathrm{E}_{2} s\right)$ (Table 1), and can be divided into two members in the ascending order: 1 st member $\left(\mathrm{E}_{2} d_{1}\right)$ and 2nd member $\left(\mathrm{E}_{2} d_{2}\right)$.

\section{Sedimentary characteristics and facies}

Four sedimentary facies (fan delta, delta, nearshore subaqueous fan, and lacustrine) have been identified within the Dainan Formation in the Gaoyou Depression based on the variations in lithology, sedimentary structures, and vertical successions.

\subsection{Fan delta}

Fan deltas occur mainly in the southern steep slope of the Gaoyou Depression, with three subfacies: fan delta plain, fan delta front, and profan delta. The fan delta plain subfacies is the subaerial part of the fan delta and contains distributary channels and back swamps. It is comparable with high-energy gravel-rich braided river facies (Blair and McPherson 1994; Lin et al. 2003; Krézsek et al. 2010). Distributary channels, which are the dominant microfacies of the fan delta plain, consist of gray or mottled conglomerate, gray conglomeratic sandstone, and coarse sandstone. The conglomerate gravels are common poorly sorted, subangular to subrounded in shape, and randomly distributed in a matrix of fine- to coarse-grained sands which indicate proximal deposition. Also, they have complex compositions, which include siliceous rocks, phyllite, limestone, mud pebbles and gypsum, and have diameters ranging from 1 to $8 \mathrm{~cm}$. The structureless conglomerates overlie basal scour surfaces and progressively change upwards into parallel-bedded conglomeratic sandstones and coarse-grained sandstones. These characteristics suggest deposition from waning high-density flows. The spontaneous potential $\operatorname{logs}(\mathrm{SP})$ are jagged with low to moderate amplitudes. The brown mudstones and silty mudstones are interpreted as deposits of a back-swamp environment.

Fan delta front subfacies consist primarily of subaqueous distributary channels and interchannels, and subordinate mouth bar and sand sheet deposits (Fig. 2). Subaqueous distributary channel microfacies are characterized by light gray conglomeratic sandstones, and gray to 


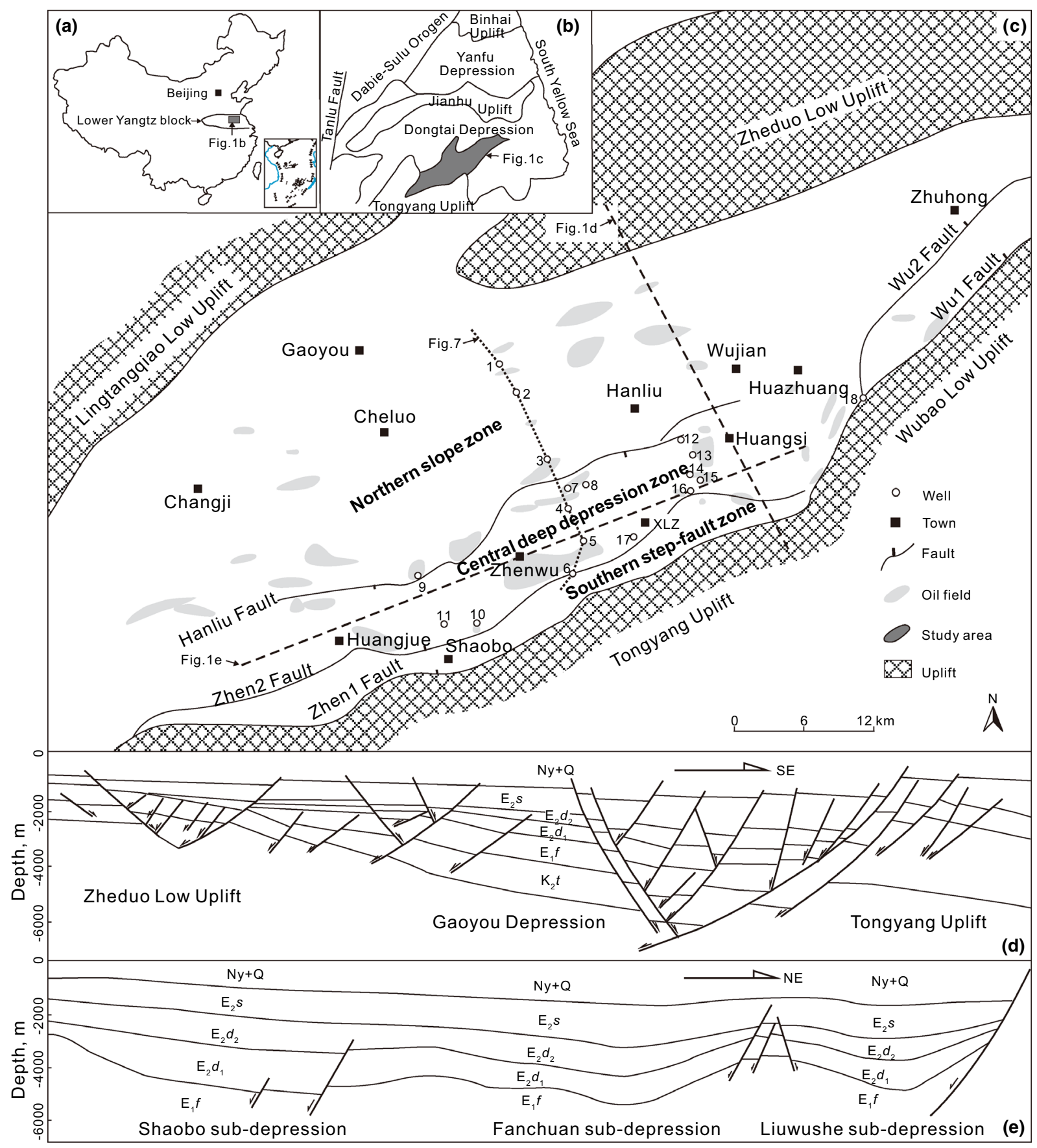

Fig. 1 a Location of the North Jiangsu Basin. b Simplified geological map of the North Jiangsu Basin and the location of the Gaoyou Depression. c Simplified geological map of the Gaoyou Depression. d, e the tectonic profiles derived from the seismogeological interpretation (see locations in c). Arabic numerals represent locations of the wells used in this paper. $1 \mathrm{Fa} \mathrm{1;} 2 \mathrm{Jia} 4 ; 3$ Yong 20; 4 Yong 14; 5 Cao 20; 6 Xu 27; 7 Yong 7; 8 Yong 16; 9 Lian 7; 10 Shao 9; 11 Shao 6; 12 Fu 16; 13 Fu 35; 14 Fu 5; 15 Fu 44; 16 Fu 23; 17 Xiao 3; 18 Zhou $52 ; \mathrm{K}_{2} t$ : Taizhou Formation; $\mathrm{E}_{1} f$ : Funing Formation; $\mathrm{E}_{2} d_{1}$ : the 1st member of the Dainan Formation; $\mathrm{E}_{2} d_{2}$ : the 2nd member of the Dainan Formation; $\mathrm{E}_{2} s$ : Sanduo Formation; Ny: Yancheng Formation; Q: Quaternary; XLZ: Xiaoliuzhuang

brown fine sandstones and siltstones which exhibit an upward-fining trend (Fig. 2). From bottom to top, sedimentary structures include a scour surface (Fig. 3a), graded bedding, tabular cross bedding (Fig. 3b), parallel bedding
(Fig. 3b), climbing-ripple cross stratification (Fig. 3c), wavy bedding, and convolute bedding (Fig. 3d). Furthermore, mud pebbles are pervasively present above the scour surface, having diameters ranging from 0.5 to $2.5 \mathrm{~cm}$, and 
Table 1 Stratigraphic division of the Paleogene Dainan Formation in the Gaoyou Depression

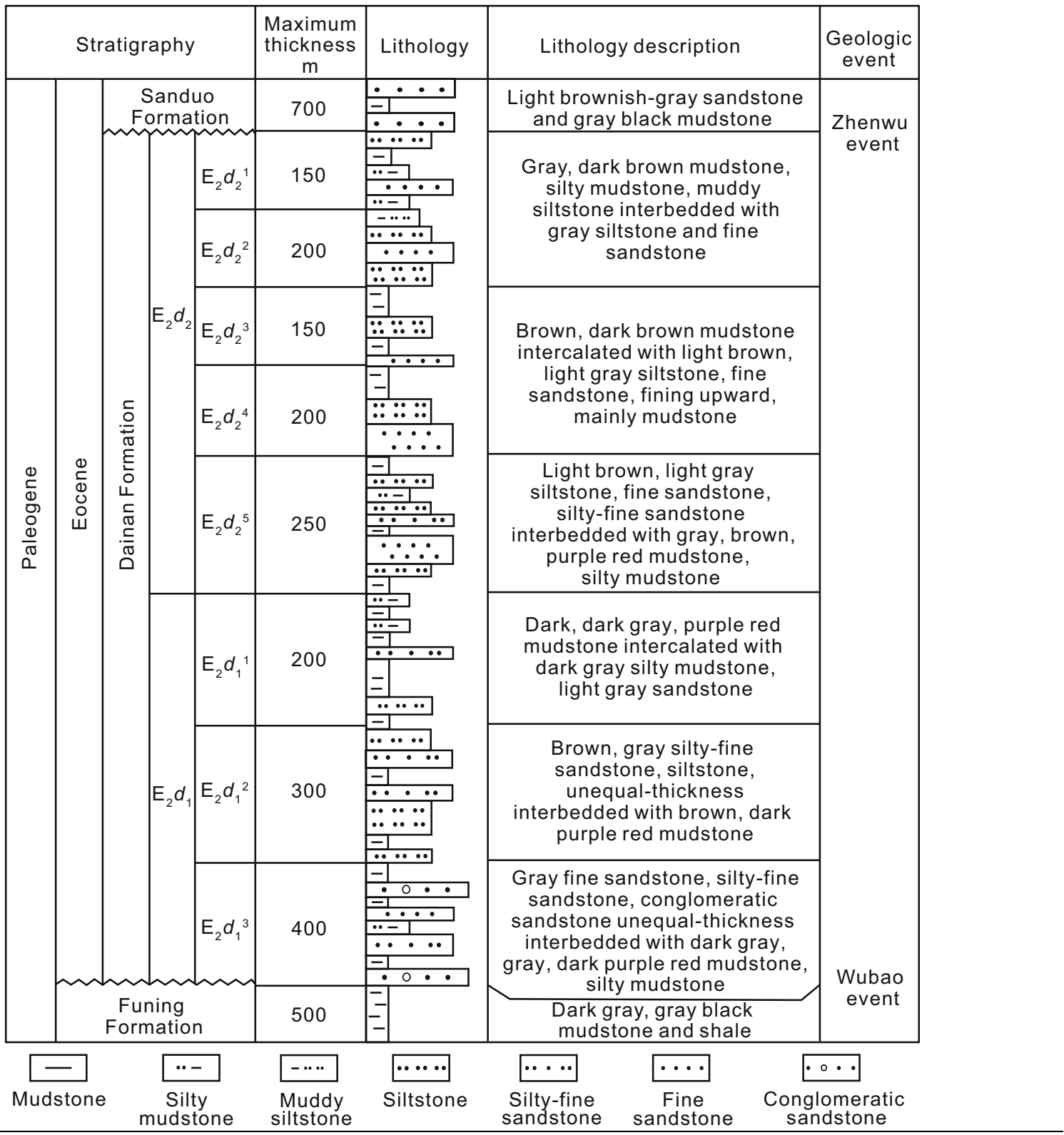

their abundance and grain size become progressively lower and smaller, respectively, towards the top (Fig. 3a). Single subaqueous distributary channels are 5-10 m thick, but they can amalgamate and superimpose upon one another with resultant thicknesses reaching more than $50 \mathrm{~m}$. SP curves display an obvious negative anomaly. Subaqueous distributary interchannel microfacies are composed of gray silty mudstones, and purple red, brown, dark gray mudstones, which together are occasionally intercalated with muddy siltstones. Horizontal, wavy, and lenticular beddings are also present, commonly having bioturbation and abundant plant remains. Mudstones of subaqueous distributary interchannels usually display significant scour and can even be completely removed by successive high-discharge events. Such mudstones are commonly laminated as indicated by the SP curves close to the shale line and resistivity log $(R)$ curves displaying a low-magnitude jagged pattern (Fig. 2). Mouth bar microfacies mainly contain gray to brown siltstone and fine-grained sandstone with a thickness of 4-6 m. These exhibit an upward-coarsening succession, as shown by the funnel-shaped SP curve. Cross, parallel, and wavy beddings are common. The sandstones 


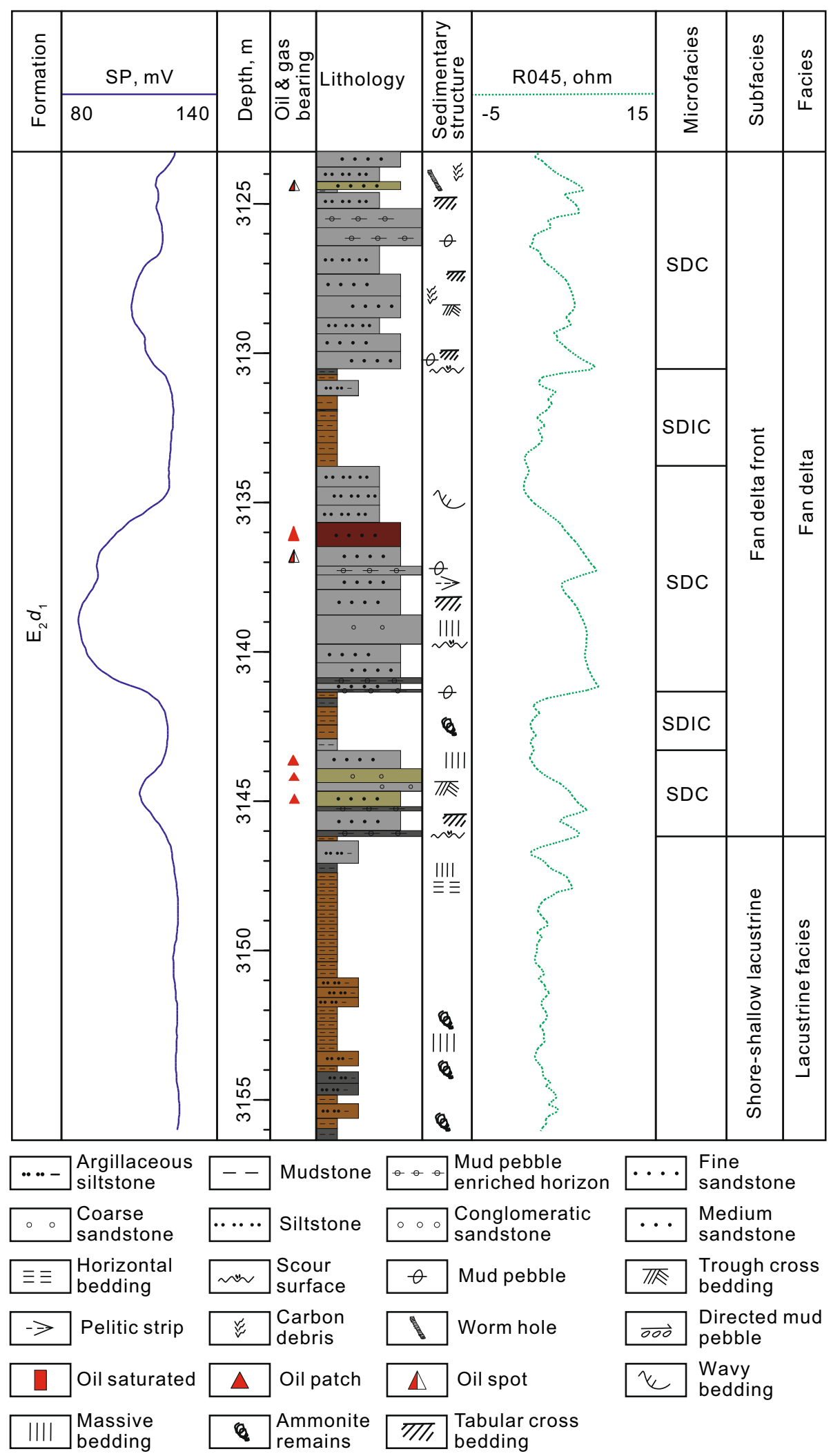

Fig. 2 Sedimentary characteristics of the fan delta for the Dainan Formation in Well Fu 35 of the Gaoyou Depression (see location in Fig. 1c). $S P$ spontaneous potential curve; R045 0.45 m potential resistivity curve. SDC Subaqueous distributary channel; SDIC Subaqueous distributary interchannel 

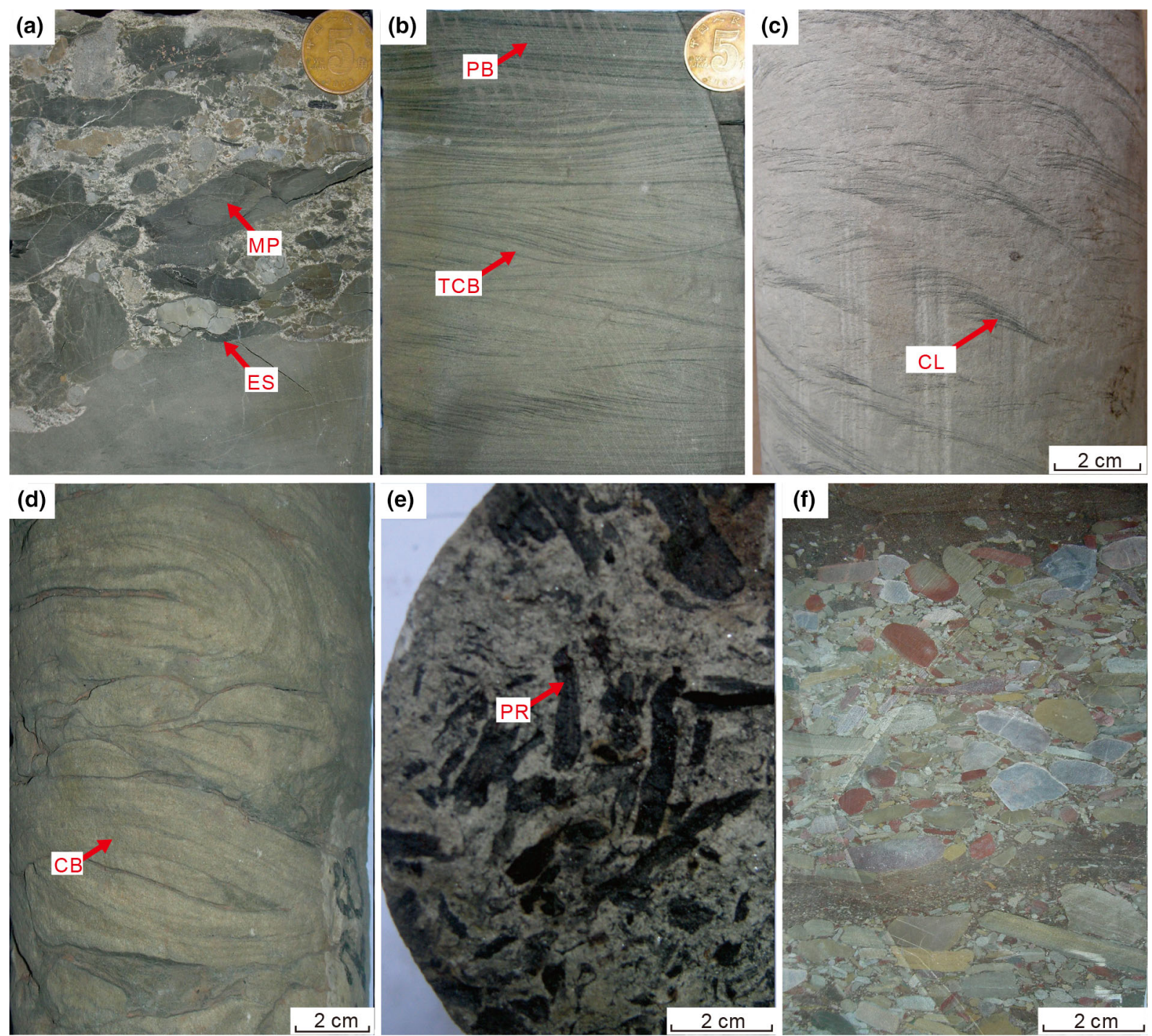

Fig. 3 Typical sedimentary structures of the Dainan Formation in the Gaoyou Depression. Subaqueous distributary channel of the fan delta front. a Erosional base surface (ES) and mud pebbles (MP), Well Fu 23, $2933.7 \mathrm{~m}$; b Tabular cross bedding (TCB) and parallel bedding (PB), Well Fu 23, $3094.6 \mathrm{~m}$; c Climbing-ripple cross stratification (CL), Well Zhou 52, $1655.8 \mathrm{~m}$; and d Convolute bedding (CB), Well Cao 20, $3251.3 \mathrm{~m}$. e Plant remains (PR) from the subaqueous interchannel in the delta front, Well Fu 35, $3126.8 \mathrm{~m}$. f Structureless mottled conglomerate from the inner fan of the nearshore subaqueous fan, Well Shao 9, $2284.5 \mathrm{~m}$. The coins in $\mathbf{a}, \mathbf{b}$ are $2 \mathrm{~cm}$ in diameter. See Fig. 1c for well locations

of subaqueous distributary channels and mouth bars were vulnerable to being reworked by wave processes (Coleman 1988; Johnson and Levell 1995; Hoy and Ridgway 2003), forming a thin-bedded, widely distributed sand sheet in the distal part of the fan delta front. Sand sheets consist mainly of siltstone and muddy siltstone and display an intimate association with the mudstones of the shallow lacustrine facies (finger-like pattern in the SP curve). The thickness of individual sand sheets is $2-3 \mathrm{~m}$.

Profan delta subfacies mainly consist of grayish brown mudstones with sand strips and masses. Horizontal bedding is most common, with wavy and lenticular beddings being less common. The SP curve is relatively straight, while the $R$ curve displays a low-amplitude jagged pattern.

\subsection{Delta}

Delta facies occur predominantly in the northern gentle slope of the Gaoyou Depression, and are marked by finegrained sandstones with less conglomerate and more mudstone compared to the fan deltas (Table 2). Seismic profiles occur as parallel to subparallel reflection configurations. The deltas can be divided into three distinct yet genetically related subfacies: delta plain, delta front, and 
Table 2 Comparisons among the fan delta, delta, and nearshore subaqueous fan facies of the Paleogene Dainan Formation

\begin{tabular}{|c|c|c|c|}
\hline & Fan delta & Delta & Nearshore subaqueous fan \\
\hline $\begin{array}{l}\text { Distribution } \\
\text { location }\end{array}$ & $\begin{array}{l}\text { Step-fault zone in the southern steep } \\
\text { slope }\end{array}$ & Northern gentle slope zone & $\begin{array}{l}\text { The single fault zone in the southern } \\
\text { steep slope }\end{array}$ \\
\hline $\begin{array}{l}\text { Sedimentary } \\
\text { characteristics }\end{array}$ & $\begin{array}{l}\text { Composed primarily of relatively } \\
\text { coarse-grained, moderately sorted, } \\
\text { and grain-supported conglomerate, } \\
\text { conglomeratic sandstone, and coarse } \\
\text { sandstone, with some siltstone and } \\
\text { mudstone } \\
\text { Cumulative grain-size distribution } \\
\text { curve presents two sections. } \\
\text { Contain sedimentary structures formed } \\
\text { by tractive currents }\end{array}$ & $\begin{array}{l}\text { Composed mainly of relatively fine- } \\
\text { grained and well-sorted fine to coarse } \\
\text { sandstones, subordinate siltstone, and } \\
\text { mudstone } \\
\text { Cumulative grain-size distribution } \\
\text { curve presents two sections } \\
\text { Contain sedimentary structures formed } \\
\text { by tractive currents }\end{array}$ & $\begin{array}{l}\text { Composed of poorly sorted and } \\
\text { coarsest-grained sedimentary rocks, } \\
\text { like matrix-supported conglomerate, } \\
\text { indicating the strongest } \\
\text { hydrodynamic force } \\
\text { Cumulative grain-size distribution } \\
\text { curve is similar to gravity flow. } \\
\text { Contain sedimentary structures formed } \\
\text { by gravity flow }\end{array}$ \\
\hline $\begin{array}{l}\text { Microfacies } \\
\text { type }\end{array}$ & $\begin{array}{l}\text { Microfacies type is monotonous, and } \\
\text { consists mainly of subaqueous } \\
\text { distributary channels and } \\
\text { interchannels of the fan delta front. } \\
\text { Fan delta plain subfacies are not well } \\
\text { developed }\end{array}$ & $\begin{array}{l}\text { Delta plain and delta front subfacies are } \\
\text { widely developed, with the latter } \\
\text { dominant. Furthermore, the delta } \\
\text { front is typified by various } \\
\text { microfacies, including subaqueous } \\
\text { branch channel, subaqueous branch } \\
\text { interchannel, branching mouth bar, } \\
\text { and sand sheet }\end{array}$ & $\begin{array}{l}\text { Dominated by inner fan and middle fan } \\
\text { subfacies, with the former including } \\
\text { one or a few main channels and the } \\
\text { latter involving braided channels and } \\
\text { channel bays }\end{array}$ \\
\hline $\begin{array}{l}\text { Distribution } \\
\text { pattern }\end{array}$ & Small-scaled lobe shape in plane view & Large-scaled lobe shape in plane view & Small-scaled lobe shape in plane view \\
\hline $\begin{array}{l}\text { Logging curve } \\
\text { property }\end{array}$ & $\begin{array}{l}\text { SP curves show prominent negative } \\
\text { anomalies, and are slightly jagged } \\
\text { with low to moderate amplitudes. R } \\
\text { curves are moderately jagged with } \\
\text { medium amplitudes. These curves } \\
\text { could show bell or cylinder shapes }\end{array}$ & $\begin{array}{l}\text { SP curves show prominent negative } \\
\text { anomalies, with moderate to high } \\
\text { amplitudes and significant negative } \\
\text { values. SP curves show pronounced } \\
\text { bell, cylinder, and funnel shapes. R } \\
\text { curves are moderately jagged with } \\
\text { relatively low values and amplitudes }\end{array}$ & $\begin{array}{l}\text { SP curves show prominent negative } \\
\text { anomalies, and are slightly serrated } \\
\text { with low to moderate amplitudes. R } \\
\text { values are extremely high, with the } \\
\text { curves being seriously jagged }\end{array}$ \\
\hline $\begin{array}{l}\text { Seismic facies } \\
\text { characteristics }\end{array}$ & $\begin{array}{l}\text { Wedge-shaped foreset with large } \\
\text { thickness }\end{array}$ & $\begin{array}{l}\text { Parallel and subparallel sheet seismic } \\
\text { reflections }\end{array}$ & $\begin{array}{l}\text { Wedge- and/or mound-shaped seismic } \\
\text { configurations }\end{array}$ \\
\hline
\end{tabular}

prodelta, with the delta front as the majority of those found in the Gaoyou Depression. The delta plain constitutes the subaerial part of the delta and mainly consists of branch channels and branch interchannels. The basal sections of branch channels are erosionally based and are typified by medium- to coarse-grained sandstones with scattered mud pebbles. They can be structureless, or contain pervasive trough-cross and parallel beddings. The upper portion of the branch-channel succession is primarily composed of fine-grained sandstones and siltstones (with occasional mudstones), containing wavy bedding and climbing-ripple cross stratification. The thickness of individual successions ranges from 6 to $8 \mathrm{~m}$.

The delta front includes subaqueous branch channels, subaqueous branch interchannels, branching mouth bars, and sheet sands (Fig. 4). Subaqueous branch channels are erosionally based, and are mainly composed of grayish brown fine-grained sandstones and siltstones, with many rounded mud pebbles at the base. Sedimentary structures comprise graded bedding, parallel bedding, cross bedding, climbing-ripple cross stratification, and horizontal bedding from bottom to top. In general, subaqueous branch channels represent an upward-fining succession with the corresponding SP curve characteristically bell-shaped (Fig. 4). The thickness of individual successions is $5-7 \mathrm{~m}$. Subaqueous branch interchannels are located between adjacent subaqueous branch channels and consist of brownish-gray mudstones and muddy siltstones. Horizontal and wavy beddings, plant remains (Fig. 3e), and bioturbations are common.

Branching mouth bars usually occur as an upwardcoarsening succession with grayish brown muddy siltstones at the bottom, and siltstones and fine-grained sandstones towards the top. Parallel, wavy, and cross beddings are pervasive (Fig. 4). The thickness of individual successions is $3-5 \mathrm{~m}$. Sheet sands are located in the distal part of the delta front, and are mainly composed of thin-bedded fine-grained sandstone and siltstone (Fig. 4) with wavy, cross, and horizontal beddings involved. The thickness of individual successions is commonly 2-3 m. Prodelta subfacies mainly consist of gray-brown mudstones and shales intercalated with thinbedded siltstones. The SP curve displays a finger-like pattern within the low-magnitude range. 


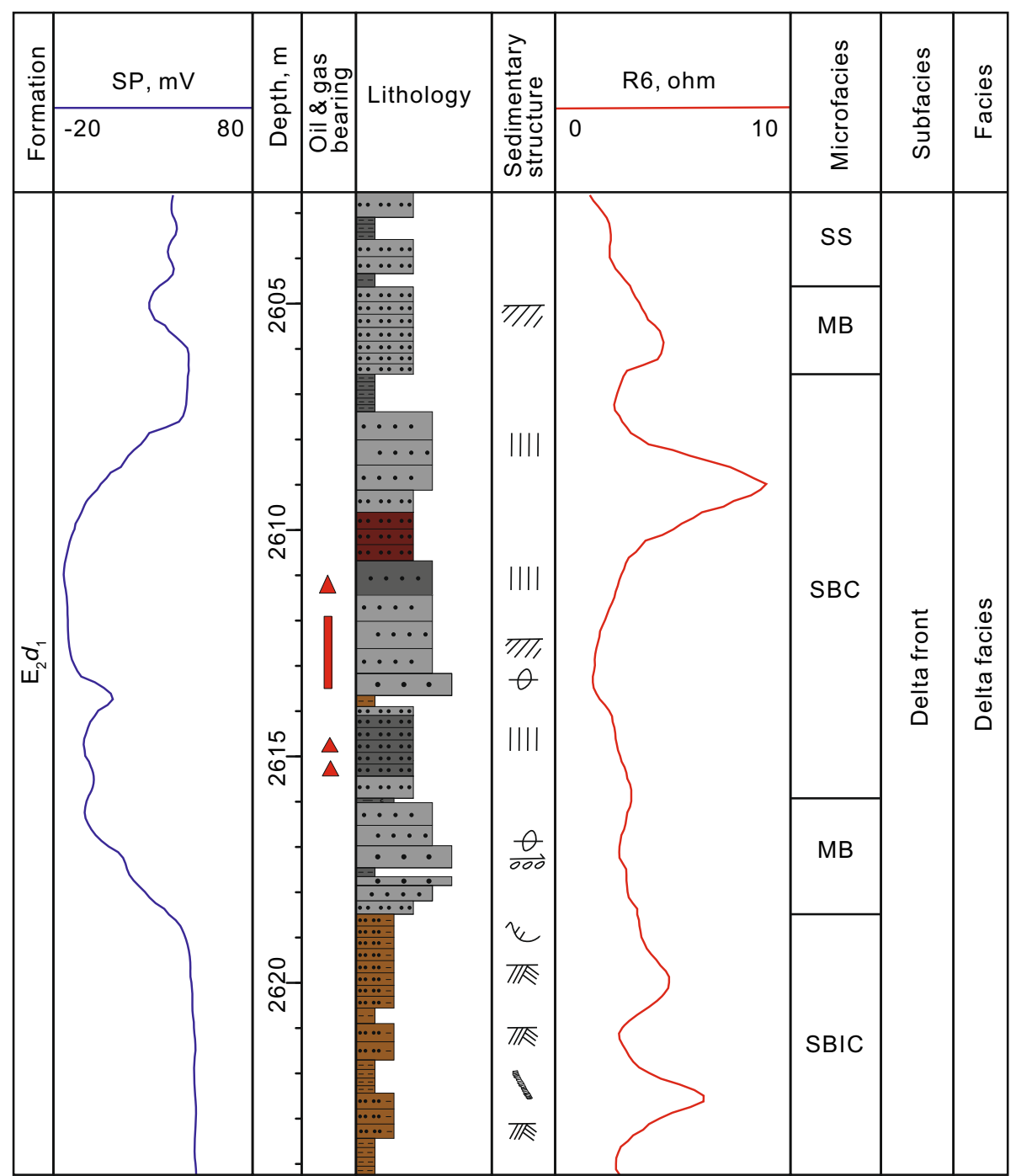

Fig. 4 Sedimentary characteristics of the delta for the Dainan Formation in Well Yong 16 (see location in Fig. 1c) of the Gaoyou Depression. SP Spontaneous potential curve; R6 $6 \mathrm{~m}$ bottom gradient resistivity curve; SS Sand sheet; $M B$ Branching mouth bar; SBC Subaqueous branch channel; SBIC Subaqueous branch interchannel. See legends in Fig. 2

\subsection{Nearshore subaqueous fan}

The term "nearshore subaqueous fan" refers to a coarsegrained fan that lacks a subaerial component. It develops where an alluvial river or fan debouches directly into excessively deep coastal waters (Colella and Prior 1993), and is derived from gravity flow (Zhang and Tian 1999; Table 2). Deposits of these systems have been commonly found in Mesozoic-Cenozoic rift basins of eastern China (Zhang and Shen 1991; Zhou et al. 1991; Zhang and Tian 1999).

In the study area, nearshore subaqueous fans developed in the Shaobo, Xiaoliuzhuang, and Zhouzhuang areas during the $\mathrm{E}_{2} d_{1}$ period, and these can be further divided into three microfacies: inner fan, middle fan, and outer fan.
The inner fan subfacies is characterized by one or a few main channels which can be described as undercompensated incised valleys (Liu 2003). The main channel consists of poorly sorted mottled conglomerates and sandy conglomerates that have complex compositions and are commonly matrix-supported and/or grain-supported. Those that are matrix-supported are interpreted to have been deposited by debris flows, characterized by gravels floating randomly in a fine-grained matrix (appearing structureless) (Fig. 3f). Resultant successions have sharp boundaries or scour surfaces at their base and load structures developed towards the underlying unit. Grain-supported conglomerates, on the other hand, are thought to have been deposited by highdensity turbidity currents. Deposits of such turbidity currents (turbidites) are typified by normal and reverse graded 
bedding, occasional crude cross bedding, and slump deformation structures. The corresponding SP curve of such successions displays a jagged bell- or cylinder-shaped pattern.

The middle fan facies includes braided channels and interchannels, with deposits of the former constituting the majority of the succession (Fig. 5). The braided channels are typified by gray and grayish-white sandy conglomerates and conglomeratic sandstones with low compositional maturity and moderate textural maturity. Clasts constituting these conglomerates involve limestone and quartz fragments with diameters of $10-20 \mathrm{~mm}$. Scour surfaces and flute casts are common at the bottom of the braided channel successions. Graded, parallel, and cross beddings are most common. The fine-grained sediments formed in the interchannels are easily washed away (Walker 1978). The corresponding SP curve displays a bell-shaped or jagged cylinder-shaped pattern (Fig. 5).

The outer fan is located in the seaward extremity of the nearshore subaqueous fan and consists mainly of dark mudstones intercalated with siltstones, muddy siltstones, and locally thinly bedded fine-grained sandstones. Sedimentary structures mainly include wavy and horizontal beddings, reflecting a relatively lower flow regime and quiet environment. The corresponding SP curve is flat with low amplitudes.

Compared to the deltas and fan deltas, the nearshore subaqueous fan is characterized by the strongest hydrodynamic force and poor sorting (Table 2), which is clearly reflected in the probability cumulative grain-size distribution curves (Fig. 6). Figure 6 shows that (1) the grain-size range of saltation components for nearshore subaqueous fans is between -1.0 and 3.0 $\Phi$, whereas those of fan delta and delta are 0.5-3.5 and 1.0-4.0 $\Phi$, respectively, which indicates that the hydrodynamic force of nearshore subaqueous fans is the strongest (Lin et al. 2005); (2) the slope of saltation components for delta, fan delta, and nearshore subaqueous fan is about $71^{\circ}, 65^{\circ}$, and $52^{\circ}$, respectively, of which the latter is the smallest, suggesting poor sorting; (3) the abundance of the suspension component for the

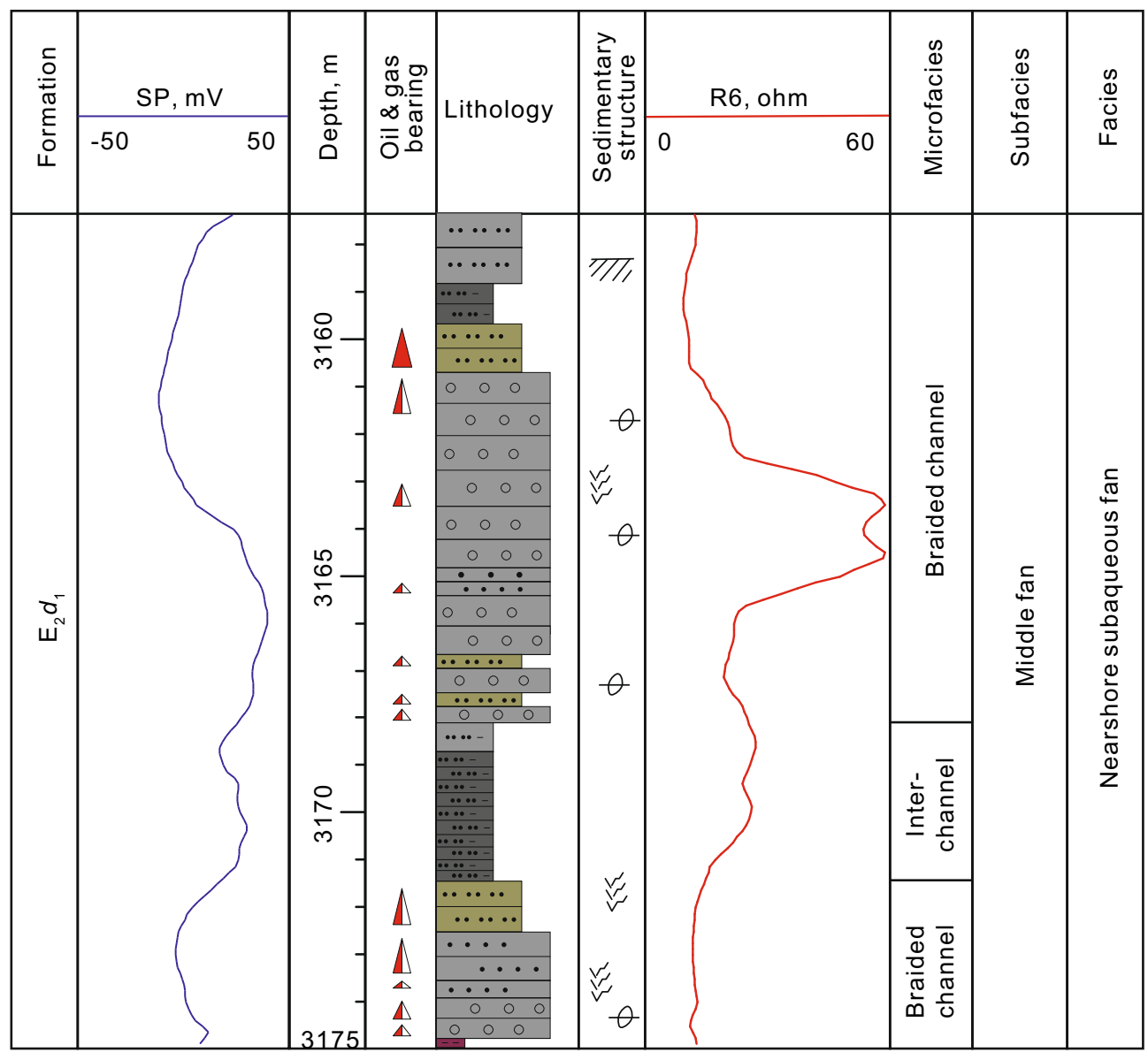

Fig. 5 Sedimentary characteristics of the nearshore subaqueous fan for the Dainan Formation in Well Xiao 3 (see location in Fig. 1c) of the Gaoyou Depression. SP Spontaneous potential curve; R6 $6 \mathrm{~m}$ bottom gradient resistivity curve. See legends in Fig. 2 

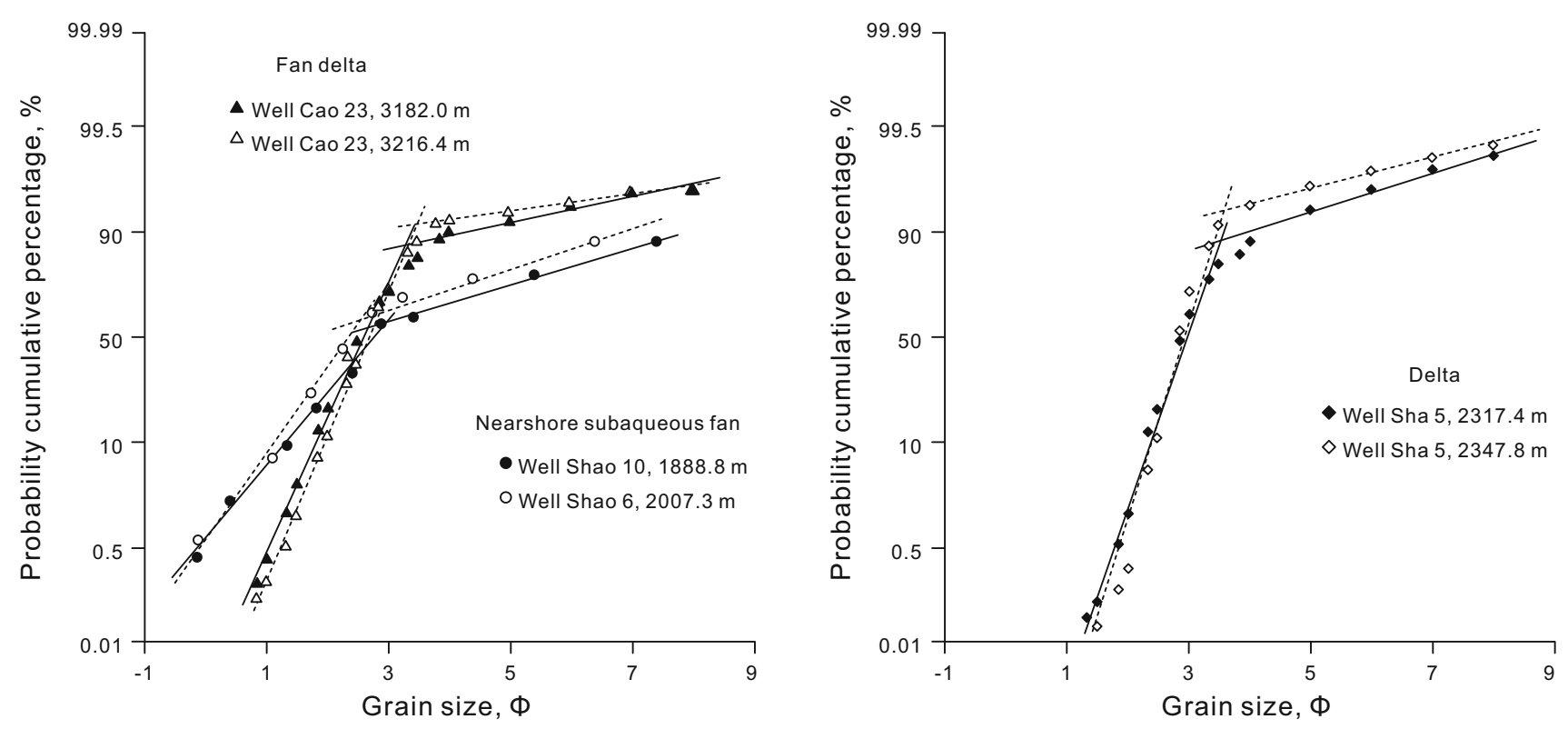

Fig. 6 Probability cumulative grain-size distribution curves of the fan delta, delta, and nearshore subaqueous fan in the Dainan Formation. See Fig. 1c for the well locations

nearshore subaqueous fans is the greatest, generally more than $30 \%$, supporting a graywacke classification.

\subsection{Lacustrine facies}

Lacustrine facies mainly occur at the center of the Gaoyou Depression, as well as on the flanks of the fan deltas, deltas, and nearshore subaqueous fans. Shoreshallow lacustrine and semideep lacustrine subfacies are identified in the study area. The nature of the shoreshallow lacustrine subfacies is controlled by the provenance and hydrodynamic force. If the provenance is typified by gravel and sand, then gravelly and/or sandy lacustrine beaches form. However, if the terrain of the lacustrine beach is gentle, the hydrodynamic force will be weak, and supplied sediment will consist mainly of mud, allowing mudflats to form (Lin et al. 2003). In the study area, the shore-shallow lacustrine subfacies comprise mainly of siltstones and mudstones with a variety of colors: brownish-gray, dark-purple, and dark-brown (Fig. 2). Horizontal and wavy beddings, bioturbation (especially vertical worm burrows), and plant remains are common. The corresponding SP curve is linear and low in amplitude, while the $R$ curve is jagged having low to moderate amplitudes (Fig. 2). Semideep lacustrine facies are located under the fair-weather wave base, i.e., a generally anoxic environment. Sedimentary rocks are mainly composed of dark mudstones with high organic matter contents, with horizontal and lenticular beddings dominant.

\section{Sedimentary distribution and processes}

The sedimentary succession of the Dainan Formation in the Gaoyou Depression exhibits a complete transgressive-regressive cycle with sediment grain sizes displaying a coarse-fine-coarse pattern in the ascending order. As a result, there are two major sedimentological periods for the Dainan Formation: $\mathrm{E}_{2} d_{1}$ and $\mathrm{E}_{2} d_{2}$. $\mathrm{E}_{2} d_{1}$ consists of three stages: $\mathrm{E}_{2} d_{1}^{3}, \mathrm{E}_{2} d_{1}^{2}$, and $\mathrm{E}_{2} d_{1}^{1}$, and $\mathrm{E}_{2} d_{2}$ is composed of five stages: $\mathrm{E}_{2} d_{2}^{5}, \mathrm{E}_{2} d_{2}^{4}, \mathrm{E}_{2} d_{2}^{3}, \mathrm{E}_{2} d_{2}^{2}$, and $\mathrm{E}_{2} d_{2}^{1}$ (Table 1).

\subsection{Sedimentary period of $E_{2} d_{1}$}

During the $\mathrm{E}_{2} d_{1}$ period, the Dainan Formation began to form and overlay the Funing Formation by an unconformity which had resulted from Wubao Movement. Deposition during the $\mathrm{E}_{2} d_{1}$ is thought to have been in phase with the uplifting of the basement and the development of northeastern faults in the Gaoyou Depression (syndepositional). The strata are thick in the south and gradually thin towards the north. The subsidence center was located in the Shaobo and Fanchuan subdepressions with strata thickness up to $900 \mathrm{~m}$. The fan delta, delta, nearshore subaqueous fan, and lacustrine facies developed within this period, representing a transgressive succession with the grain size of clastic particles fining upwards and the relative thickness of sandstones reducing gradually upwards (Fig. 7).

In $\mathrm{E}_{2} d_{1}^{3}$, the strong movements of the Zhen 2 and Hanliu faults controlled and limited the distribution of sediments (Chen 2001), so that the Zhen 2 fault acted as a southern 




Fig. 7 Cross-sectional profile showing the vertical evolution and distribution pattern of the different sedimentary facies of the Dainan Formation in the Gaoyou Depression. The Dainan Formation presents as an integrated transgressive-regressive cycle. See Fig. 1c for the location. $S P$ Spontaneous potential curve $(\mathrm{mV})$

boundary and the Hanliu fault formed a fault-step zone as the northern margin. The subsidence center is located in the Shaobo subdepression with stratum thickness up to $400 \mathrm{~m}$ (Fig. 8a). The total sandstone thickness is greater in the east than in the west, reaching up to $60 \mathrm{~m}$ in the Fumin area (generally 20-40 m) (Fig. 8b). Four fan deltas (Huangjue (HJ), Zhenwu-Caozhuang (ZC), Fumin (FM), Zhouzhuang (ZZ)) and a nearshore subaqueous fan (Shaobo (SB)) developed along the Zhen 2 fault. Four small-scale and independent deltas involving the western part of Lianmengzhuang (LLZ), and eastern parts of Lianmengzhuang (RLZ), Yong' an (YA) and Fumin-Huazhuang (FH) were formed on the gentle northern slope (Fig. 9a). Shore-shallow lacustrine facies occurred mainly in the center of the depression (Fig. 9a).

In $\mathrm{E}_{2} d_{1}^{2}$, the sedimentary area extended with the boundary crossing the Zhen 2 and Hanliu faults because of the small-scale increase of lake water and decrease in tectonic activity (Fig. 9b). The stratigraphic overlap in the northern part of the Gaoyou Depression is easily observed in the seismic profile. The subsidence center was also located in the Shaobo and Fanchuan subdepressions with a thickness of $300 \mathrm{~m}$ (Fig. 8c). The gross sandstone thickness is greater in the east than towards the west, with maximum thickness reaching $80 \mathrm{~m}$ in the Fumin and Yong' an areas (20-40 $\mathrm{m}$ in general) (Fig. 8d). Compared to the $\mathrm{E}_{2} d_{1}^{3}$, the range and scale of the $\mathrm{E}_{2} d_{1}^{2}$ period fan delta, delta deposits, and nearshore subaqueous fan sediments expanded due to augmented accommodation and sufficient sediment supply. Four fan deltas (HJ, ZC, FM, and ZZ) and three nearshore subaqueous fans (SB, Xiaoliuzhuang (XLZ), and ZZ) developed along the steep southern slope zone (Fig. 9b). Also, the four deltas of $\mathrm{E}_{2} d_{1}^{3}$ in the northern slope of the Gaoyou Depression merged to form one larger delta, and the Majiazui (MJZ) area started receiving sediment in this stage, resulting in the formation of two detached deltas (Fig. 9b). Shore-shallow lacustrine deposits mainly accumulated in the center of the depression, as well as on the flanks of the fan deltas, deltas, and nearshore subaqueous fans (Fig. 9b).

During the $\mathrm{E}_{2} d_{1}^{1}$ period, the lake transgression reached a maximum and the lateral extent of deposition continued to expand with the "five high-conductivity" dark mudstones representing the sedimentary boundary of the Gaoyou Depression. The subsidence center was still located in the Shaobo, Fanchuan, and Liuwushe subdepressions with strata thickness of $200 \mathrm{~m}$ (Fig. 8e). The gross sandstone thickness is generally $20 \mathrm{~m}$, but can be locally greater, such as in the Fumin, Yong'an, and Shanian areas, where thicknesses can reach up to $40 \mathrm{~m}$ (Fig. 8f). Compared to the $\mathrm{E}_{2} d_{1}^{3}$ and $\mathrm{E}_{2} d_{1}^{2}$, the scales of fan deltas, deltas and nearshore subaqueous fans of the $\mathrm{E}_{2} d_{1}^{1}$ period were reduced 

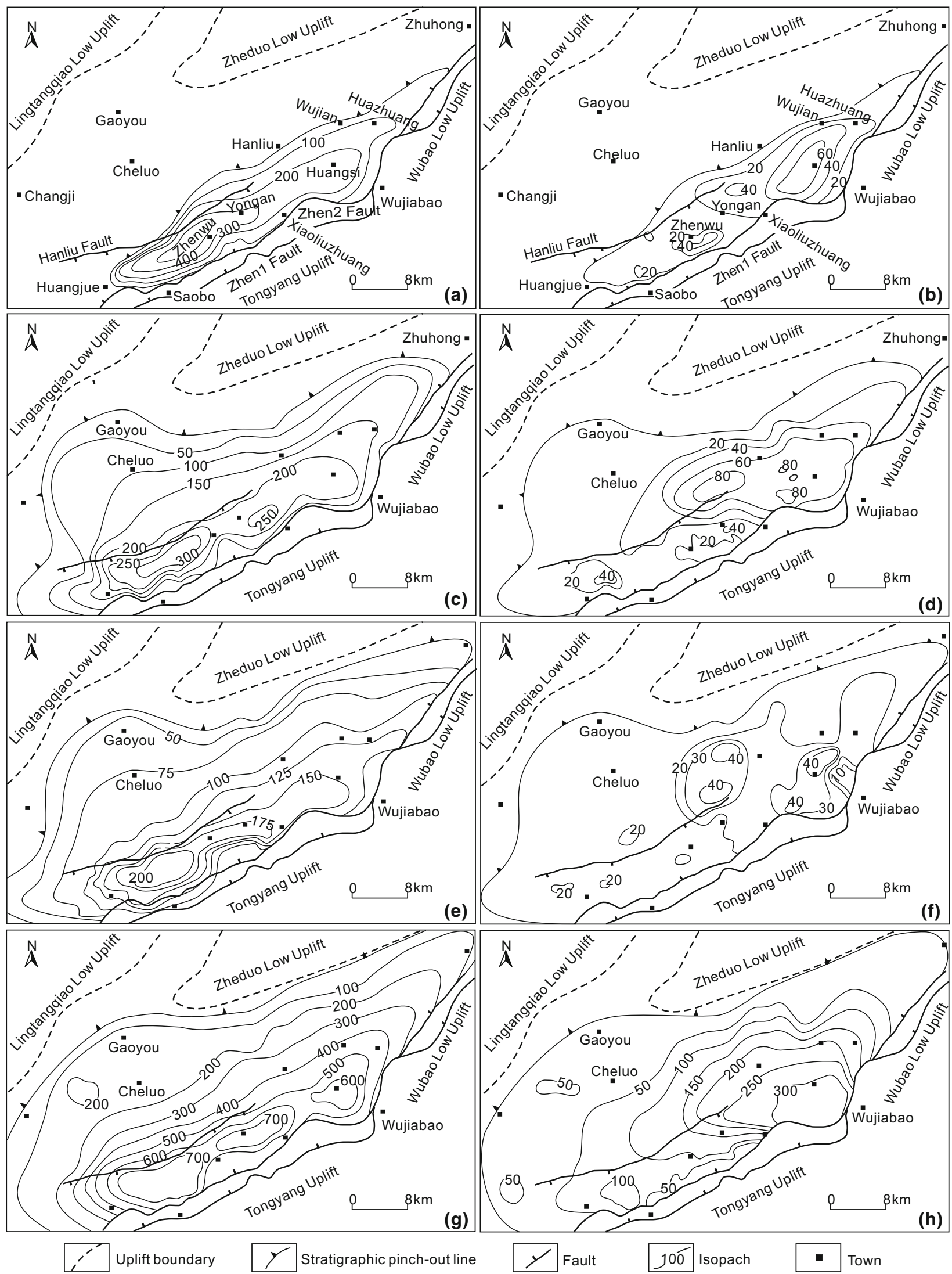
4Fig. 8 Isopach maps of the strata (left side) and gross sandstone layers (right side) in different stages for the Dainan Formation, Gaoyou Depression. a, b The $\mathrm{E}_{2} d_{1}^{3}$ stage; c, d: the $\mathrm{E}_{2} d_{1}^{2}$ stage; $\mathbf{e}, \mathbf{f}$ the $\mathrm{E}_{2} d_{1}^{1}$ stage; $\mathbf{g}, \mathbf{h}$ the $\mathrm{E}_{2} d_{2}$ stage

and these moved back towards the lakeshore. The ZC and $\mathrm{ZZ}$ fan deltas of $\mathrm{E}_{2} d_{1}^{2}$ were each replaced with two detached and small-scale fan deltas. In the northern slope, the delta was still a unified delta as that of $\mathrm{E}_{2} d_{1}^{2}$. The Wazhuang (WZ) area started receiving sediment in this stage occurring as the WZ delta. The $\mathrm{ZZ}$ nearshore subaqueous fan was substituted by shore-shallow lacustrine subfacies. Semideep lacustrine subfacies developed in the Shaobo, Fanchuan, and Liuwushe subdepressions, and the shore-shallow lacustrine subfacies deposited mainly on the flanks of fan deltas, deltas, and nearshore subaqueous fans (Fig. 9c).

\subsection{Sedimentary period of $E_{2} d_{2}$}

During the $\mathrm{E}_{2} d_{2}$ period, the Gaoyou Depression was characterized by weak movement of faults and basement uplift, resulted in a shallowing water depth, a decreasing slope gradient, and disappearance of nearshore subaqueous fans in the southern slope (Figs. 9d, 10). The stratum thickness is still thick in the south and thins out towards the north (Fig. 8g). Subsidence centers were located in the Shaobo and Fanchuan subdepressions with strata thicknesses up to $700 \mathrm{~m}$ (Fig. 8g). The sandstones were primarily deposited in the eastern Gaoyou Depression, including the Shanian and Yong'an areas of the northern slope, as well as the Fumin and Fanchuan regions of the southern slope, with thicknesses commonly reaching 100-300 m. These thicknesses generally thin out towards the western Gaoyou Depression to approximately $<50 \mathrm{~m}$, with only a few areas reaching $100 \mathrm{~m}$ (Fig. 8h). In general, the sedimentary framework of $\mathrm{E}_{2} d_{2}$ occurs as a regressive succession composed of a second-order transgressive-regressive cycle, with the grain size and thickness of the sandstone displaying a coarse-fine-coarse and thick-thinthick trend upwards, respectively (Fig. 7).

During the $\mathrm{E}_{2} d_{2}^{5}$ depositional period, the dispersal of sediment reduced and water depth became shallower compared to $\mathrm{E}_{2} d_{1}^{1}$. Due to the sufficient supply of sediment, the fan deltas in the steep southern slope and the deltas in the northern gentle slope prograded into the center of the depression with their lateral extent amplified. In the Fumin area, the fan delta front and delta front converged (Fig. 9d). The Zhenwu and Caozhuang fan deltas of the $\mathrm{E}_{2} d_{1}^{1}$ period also joined together as one unified fan delta. Semideep lacustrine subfacies were replaced by shore-shallow lacustrine subfacies (Fig. 9d).
In $\mathrm{E}_{2} d_{2}^{4}$, the lateral extent of sediment deposition extended and water depth increased compared to $\mathrm{E}_{2} d_{2}^{5}$. Together, this resulted in the retrogradation of the fan deltas and deltas with the scale of such systems reduced. The fan delta fronts and delta fronts, however, still converged in the Fumin area. The Zhenwu-Caozhuang and Shaobo fan deltas and Lianmengzhuang-Yong'an-Fumin delta of the $\mathrm{E}_{2} d_{2}^{5}$ period were each replaced by two detached and small-scale fan deltas and deltas. Shoreshallow lacustrine subfacies developed in the center of the depression and on the flanks of deltas/fan deltas (Fig. 9e).

In $\mathrm{E}_{2} d_{2}^{3}$, the water depth continued to increase, which resulted in the persistent retrogradation of the fan deltas and deltas. The fan delta front and delta front separated in the Fumin area. The Lianmengzhuang and Yong'an-Fumin delta of the $\mathrm{E}_{2} d_{2}^{4}$ period converged into a unified delta, and the two separated fan deltas in the Shaobo area also joined together. Shore-shallow lacustrine subfacies developed in the center of the depression and on the flanks of deltas/fan deltas (Fig. 9f).

In $\mathrm{E}_{2} d_{2}^{2}$, the distribution pattern of sedimentary facies is similar to that of the $\mathrm{E}_{2} d_{2}^{3}$ period; however, the deltas and fan deltas prograded into the center of the depression with the scale of lateral deposition increased due to the shallow water depth and sufficient supply of sediment (Fig. 9g).

In $\mathrm{E}_{2} d_{2}^{1}$, the deltas and fan deltas continued to prograde into the center of depressions with the scales increased due to the shallow water depth and sufficient supply of sediment. In the Fumin area, the fan delta front and delta front met and blended together again. The Huangjue and Shaobo fan deltas also merged together to form a unified fan delta (Fig. 9h). In addition, during the late stage of the $\mathrm{E}_{2} d_{2}^{1}$ period, the Gaoyou Depression uplifted as a result of Zhenwu Movement leading to the denudation of Dainan Formation which was unconformably overlain by the Sanduo Formation (Table 1).

\section{Sedimentary architecture and implications}

Continental rift basin sediment filling patterns are mainly controlled by tectonics (Lin et al. 2001), and subordinate lake-level fluctuations and sediment supply ( $\mathrm{Yu}$ et al. 2007). Tectonics primarily determines the type of sedimentary facies present and the associated spatial distribution pattern. The southern slope of the Gaoyou Depression was steep and narrow such that the increased rate of accommodation creation, triggered by tectonically induced subsidence (fault movements), exceeded the rate of sediment supply $(A>S)$. As a result, small-scale and coarsegrained fan deltas and nearshore subaqueous fans preferentially developed (Fig. 11). For instance, in step-fault zones such as the Huangjue and Fumin areas, the slope was 

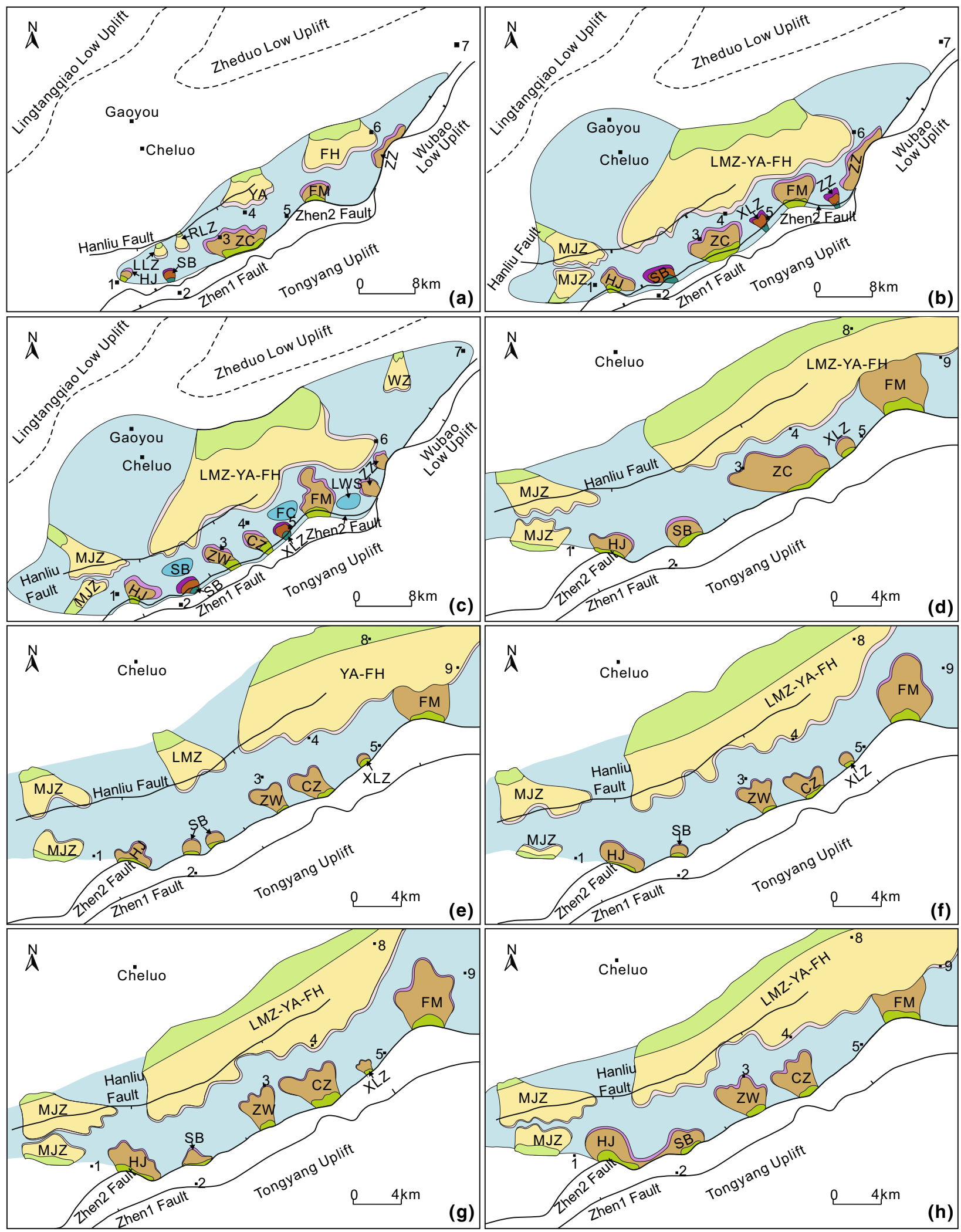

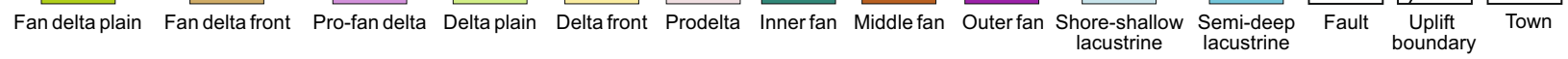


4Fig. 9 Diagrams showing the distribution pattern of the different sedimentary facies in plan view for different stages during the development of the Dainan Formation, Gaoyou Depression. a $\mathrm{E}_{2} d_{1}^{3}$ stage; b $\mathrm{E}_{2} d_{1}^{2}$ stage; $\mathbf{c} \mathrm{E}_{2} d_{1}^{1}$ stage; $\mathbf{d} \mathrm{E}_{2} d_{2}^{5}$ stage; $\mathbf{e} \mathrm{E}_{2} d_{2}^{4}$ stage; $\mathbf{f} \mathrm{E}_{2} d_{2}^{3}$

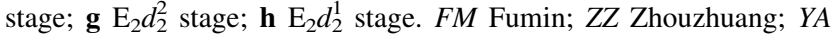
Yong'an; FH Fumin-Huazhuang; RLZ Right part of the Lianmengzhuang; LLZ Left part of the Lianmengzhuang; $H J$ Huangjue; $S B$ Shaobo; ZC Zhenwu-Caozhuang; MJZ Majiazui; XLZ Xiaoliuzhuang; WZ Wazhuang; $Z W$ Zhenwu; $C Z$ Caozhuang; $L M Z-Y A-F H$ Lianmengzhuang-Yong' an-Fumin-Huazhuang; $F C$ Fanchuan; LWS Liuwushe; LMZ Lianmengzhuang; $Y A-F H$ Yong'an-Fumin-Huazhuang. Arabic numbers show the town locations in the study area, 1 Huangjue; 2 Shaobo; 3 Zhenwu; 4 Yong'an; 5 Xiaoliuzhuang; 6 Huazhuang; 7 Zhuhong; 8 Hanliu; 9 Huangsi

(a) First member of the Dainan Formation $\left(\mathrm{E}_{2} d_{1}\right)$ : large slope angle and high lake level

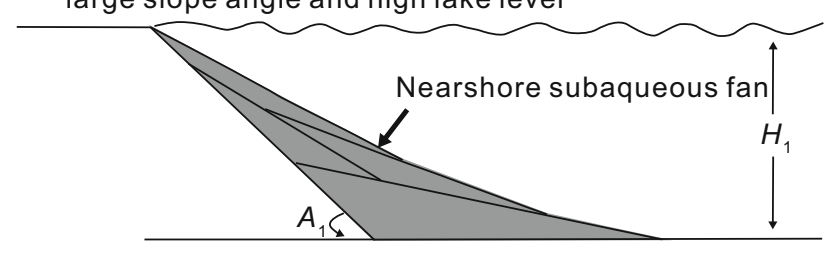

(b) Second member of the Dainan Formation $\left(E_{2} d_{2}\right)$ : small slope angle and low lake level

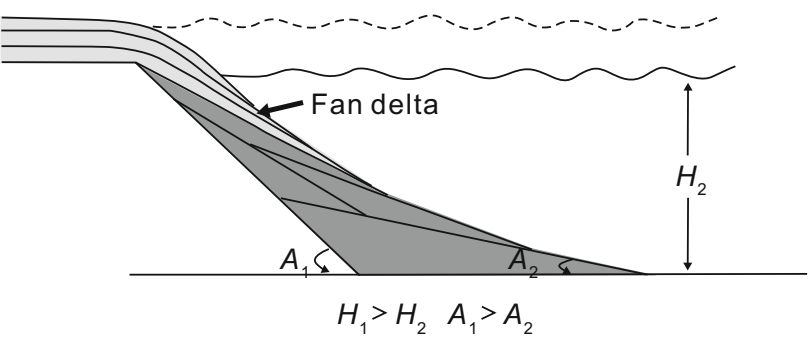

Fig. 10 Schematic map showing how the slope gradient and lake level control the formation of the nearshore subaqueous fan and fan delta. $H_{1}$ represents the water depth; $A_{1}$ indicates the slope angle

relatively gentle enough to allow for the development of fan deltas. In the monofaulted zone, like the Shaobo area, however the slope was sufficiently steep to form nearshore subaqueous fans (Figs. 10, 11). The northern slope was broad and gentle characterized by decreased subsidence as a result of reduced movement of faults, therefore favoring the generation of large-scale fine-grained deltas (Fig. 11). Lake-level fluctuations and sediment supply modulated the distribution pattern and scale of sand bodies by modifying the interrelationship between the rates of accommodation space creation and sediment supply. The rate of sediment supply was able to keep pace with, or exceeded, the increased rate of accommodation space creation. Numerous studies have shown that lake-level fluctuations can cause a shift in the depocenter, which results in the deposition of a wide range of sedimentary facies in the same area of the basin through each transgressive-regressive cycle as shown in Fig. 7 (Posamentier et al. 1988; Hoy and Ridgway 2003).

Economically important reservoirs in the Gaoyou Depression consist predominantly of deltaic and fan deltaic sandstones which are mainly distributed along the margins of depressions. Additionally, the reservoir quality of sandstones in the subaqueous branch channels of the deltas is generally better than that of sandstones in the subaqueous distributary channels of the fan deltas. Porosity of the former ranges from $10 \%$ to $30 \%$, and the permeability ranges from 1 to $100 \mathrm{mD}$. The porosity and permeability of the latter, however, are $10 \%-20 \%$ and $<1 \mathrm{mD}$, respectively. The sandstones of nearshore subaqueous fans represent a second reservoir type, consisting mainly of thickbedded, turbiditic channel-fill sandstones. Some turbiditic channel sandstones have been proven to be important oil reservoirs in the Gaoyou and other depressions (Zhang and Tian 1999; Gao et al. 2009). Thus, a comprehensive understanding of the vertical evolution and distribution patterns of the sedimentary facies of the Dainan Formation in the Gaoyou Depression is of significance in predicting optimal reservoir targets for exploration and exploitation.

\section{Conclusions}

The Dainan Formation in the Gaoyou Depression was generated during two major sedimentation periods $\left(\mathrm{E}_{2} d_{1}\right.$ and $\mathrm{E}_{2} d_{2}$ ), involving four main sedimentary facies, which include fan delta, delta, nearshore subaqueous fan, and lacustrine facies. In addition, the nearshore subaqueous fan facies were absent during the $\mathrm{E}_{2} d_{2}$ period due to the weak movement of faults, shallowing of the water depth, and reduction of the slope gradient. Fan delta and nearshore subaqueous fan facies are distributed predominantly in the southern steep slope, whereas deltaic facies occur in the northern gentle slope. The lacustrine facies are present in the center of the depression and on the flanks of the three facies above. Vertically, the Dainan Formation exhibits an integrated transgressive-regressive cycle with the grain size and relative thickness of sandstones displaying a coarse-fine-coarse and thick-thin-thick trend upwards, respectively. This sedimentary framework and distribution patterns of facies are thought to have been controlled primarily by tectonics, and less by lake level and sediment supply. This study provides a valuable model for the exploration and exploitation of oil and gas in the study area, as the sandstones of the subaqueous distributary channel and subaqueous branch channel facies have favorable physical properties for major lithologic reservoir targets. 


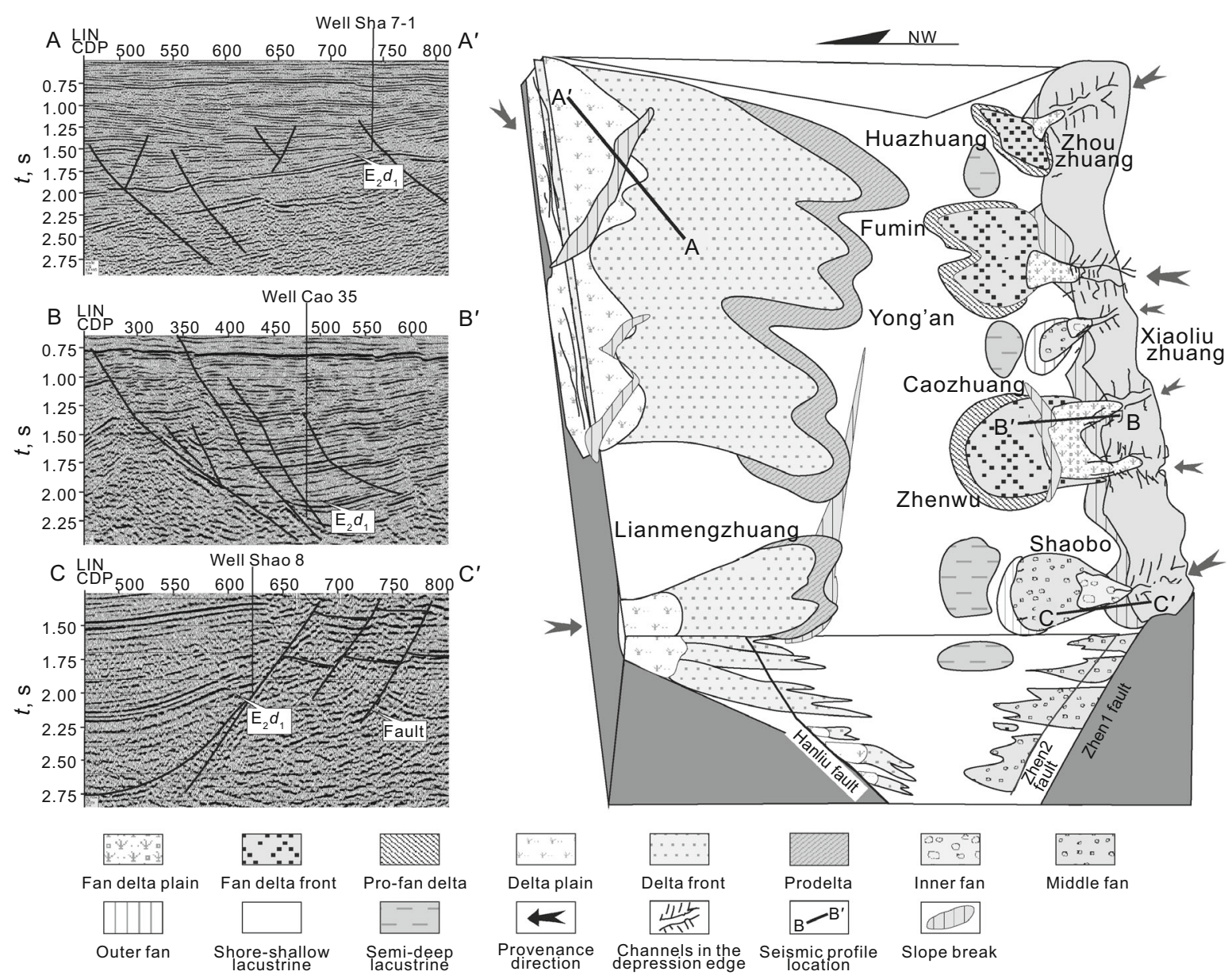

Fig. 11 The sedimentary architecture for the first member of the Dainan Formation $\left(\mathrm{E}_{2} d_{1}\right)$ in the Gaoyou Depression. Fan deltas and nearshore subaqueous fans are distributed in the southern steep slope, and deltas in the northern gentle slope. Lacustrine facies developed in the center of the depression and on the flanks of the fan deltas, deltas, and nearshore subaqueous fans

Acknowledgments This research was financially supported by the National Natural Science Foundation of China (Grants Nos. 41272124 and 41402092), Natural Science Foundation (Youth Science Fund Project) of Jiangsu Province (BK20140604), the Fundamental Research Funds for the Central Universities (20620140386), and the State Key Laboratory for Mineral Deposits Research of Nanjing University (Grant No. ZZKT-201321). We thank X.D. Yue, Y.L. Li, Z.P. Zhang, Y.L. Yao, and L.K. Gao for their helpful discussions, and assistance in field and core observations, and the laboratory work. Especial thanks are given to Y.J. Ma and Q.D. Liu of Jiangsu Oilfield Branch Company, SINOPEC for their invaluable support. Special thanks should be extended to the Petroleum Science editors and anonymous reviewers for their constructive suggestions and comments, and to D.T. Canas of Queen's University, Canada for checking the English presentation.

Open Access This article is distributed under the terms of the Creative Commons Attribution 4.0 International License (http://crea tivecommons.org/licenses/by/4.0/), which permits unrestricted use, distribution, and reproduction in any medium, provided you give appropriate credit to the original author(s) and the source, provide a link to the Creative Commons license, and indicate if changes were made.

\section{References}

Blair TC, McPherson JG. Alluvial fans and their natural distinction from rivers based on morphology, hydraulic processes, sedimentary processes, and facies assemblages. J Sediment Res. 1994;64a:450-89.

Cao YC, Yuan GH, Li XY, et al. Characteristics and origin of abnormally high porosity zones in buried Paleogene clastic reservoirs in the Shengtuo area, Dongying Sag, East China. Pet Sci. 2014;11(3):346-62.

Chen AD. Dynamic mechanism of formation of dustpan subsidence, Northern Jiangsu. Geol J Chin Univ. 2001;7(4):408-18 (in Chinese).

Chen QH, Wu L, Zhou YC. Hydrocarbon accumulation conditions and modes in the area around Shabo sub-sag, Gaoyou Sag. J Chin Unic Min Technol. 2015;44(2):282-91 (in Chinese).

Chen ZR, Wu JY. Early deposition feature of Dainan Formation in the west of Gaoyou Depression and its relation to oil and gas. Small Hydrocarbon Reserv. 2006;11(2):11-4 (in Chinese).

Colella A, Prior D. Coarse-grained deltas. Spec Publ 10 of the IAS. Oxford: Blackwell; 1993. p. 29-168. 
Coleman JM. Dynamic changes and processes in the Mississippi River delta. GSA Bull. 1988;100(7):999-1015.

Dong RX. Evolution of paleontology and sedimentary environment in Dainan-Sanduo Formation of the Tertiary Gaoyou Depression. J Tongji Univ. 1999;27(3):366-70 (in Chinese).

Gao ZY, Guo HL, Zhu RK, et al. Sedimentary response of different fan types to the Paleogene-Neogene basin transformation in the Kuqa Depression, Tarim Basin, Xinjiang Province. Acta Geol Sin. 2009;83(2):411-24.

Hoy RG, Ridgway KD. Sedimentology and sequence stratigraphy of fan-delta and river-delta deposystems, Pennsylvanian Minturn Formation, Colorado. AAPG Bull. 2003;87(7):1169-91.

Ji YL, Li QS, Wang Y, et al. Fan delta sedimentary system and facies models of Dainan Formation of Paleogene in Gaoyou Sag. J Earth Sci Environ. 2012;34(1):9-19 (in Chinese).

Jiang ZX, Liang SY, Zhang YF, et al. Sedimentary hydrodynamic study of sand bodies in the upper subsection of the 4th Member of the Paleogene Shahejie Formation in the eastern Dongying Depression, China. Pet Sci. 2014;11(2):189-99.

Johnson HD, Levell BK. Sedimentology of a transgressive, estuarine sand complex: the Lower Cretaceous Woburn Sands (Lower Greensand), southern England. In: Plint AG, editor. Sedimentary Facies Analysis. Spec Publ of the IAS, vol. 22. Oxford: Blackwell; 1995. p. 17-46.

Krézsek C, Filipescu S, Silye L, et al. Miocene facies associations and sedimentary evolution of the Southern Transylvanian Basin (Romania): implications for hydrocarbon exploration. Mar Pet Geol. 2010;27(1):191-214.

Lin CM, Li GY, Zhuo HC, et al. Sedimentary facies of incised valley fillings of the Late Quaternary in Hangzhou Bay area and shallow biogenic gas exploration. J Palaeogeogr. 2005;7(1):12-24 (in Chinese).

Lin CM, Song N, Mu R, et al. Sedimentary facies and evolution of Late Cretaceous in the Yanfu Depression from Jiangsu Province. Acta Sedimentol Sin. 2003;21(4):553-9 (in Chinese).

Lin CS, Kenneth E, Li ST, et al. Sequence architecture, depositional systems, and controls on development of lacustrine basin fills in part of the Erlian Basin, Northeast China. AAPG Bull. 2001;85(11):2017-43.

Liu ZJ. Lacus subaqueous fan sedimentary characteristics and influence factors: a case study of Shuangyang Formation in Moliqing fault subsidence of Yitong Basin. Acta Sedimentol Sin. 2003;21(1):148-54 (in Chinese).

Lu HM. Continental sequence stratigraphy study of Gaoyou Sag in Subei Basin. Fault-block Oil Gas Field. 2000;7:18-22 (in Chinese).

Pang JM, Cao B. Origin and exploration practice of $\mathrm{E}_{2} \mathrm{~d}$ concealed oil and gas accumulation in Gaoyou Depression. Offshore Oil. 2005;25(3):7-13 (in Chinese).

Posamentier HW, Jervey MT, Vail PR. Eustatic controls on clastic deposition I-conceptual framework. In: Wilgus CK, Hastings BS, Kendall CGStC, et al., editors. Sea-level changes: an integrated approach, vol. 42. Tulsa: SEPM Spec Publ.; 1988. p. 109-24.

Qiu XM, Liu YR, Fu Q. Sequence stratigraphy and sedimentary evolution of cretaceous to tertiary in Subei Basin. Beijing: Geological Publishing House; 2006. p. 17-21 (in Chinese).

Shu LS, Wang B, Wang LS, et al. Analysis of northern Jiangsu prototype basin from Late Cretaceous to Neogene. Geol J Chin Univ. 2005;11(4):534-43 (in Chinese).

Sui FG. Characteristics of reservoiring dynamic on the sandconglomerate fan bodies in the steep-slope belt of continental fault basin: a case study on Dongying Depression. Oil Gas Geol. 2003;24(4):335-40 (in Chinese).
Walker RG. Deep-water sandstone facies and ancient submarine fans: models for exploration for stratigraphic traps. AAPG Bull. 1978;62:932-66.

Wang YZ, Cao YC, Ma BB, et al. Mechanism of diagenetic trap formation in nearshore subaqueous fans on steep rift lacustrine basin slopes: a case study from the Shahejie Formation on the north slope of the Minfeng Subsag, Bohai Basin, China. Pet Sci. 2014;11(4):481-94.

Xia LJ, Wu XY, Mao SL, et al. Seismic prediction of nearshore subaqueous fan in Shaobo, Gaoyou Depression. Prog Explor Geophys. 2008;31(3):212-8 (in Chinese).

Xian BZ, Wang YS, Zhou TQ, et al. Distribution and controlling factors of glutinite bodies in the actic region of a rift basin: an example from Chezhen Sag, Bohai Bay Basin. Pet Explor Dev. 2007;34(4):429-36 (in Chinese).

Yu XH, Jiang H, Li SL, et al. Depositional filling models and controlling factors on Mesozoic and Cenozoic fault basins of terrestrial facies in eastern China: a case study of Dongying Sag of Jiyang Depression. Lithol Reserv. 2007;19(1):39-45 (in Chinese).

Zeng P. Synthetic interpretation of the G78 profile and tectonic characteristics of North Jiangsu Basin. J Oil Gas Technol. 2007;29(3):82-6 (in Chinese).

Zhang JL, Shen F. Characteristics of nearshore subaqueous fan reservoir in Damoguaihe Formation, Wuerxun Depression. Acta Pet Sin. 1991;12(3):25-35 (in Chinese).

Zhang M, Tian JC. The nomenclature, sedimentary characteristics and reservoir potential of nearshore subaqueous fans. Sediment Facies Palaeogeogr. 1999;19(4):42-52 (in Chinese).

Zhang Q, Zhu XM, Steel RJ, et al. Variation and mechanisms of clastic reservoir quality in the Paleogene Shahejie Formation of the Dongying Sag, Bohai Bay Basin, China. Pet Sci. 2014a;11(2):200-10.

Zhang N, Lin CM, Zhang X. Petrographic and geochemical characteristics of the Paleogene sedimentary rocks from the North Jiangsu Basin, East China: implications for provenance and tectonic setting. Miner Pet. 2014b;108(4):571-88.

Zhang XB, Zheng RC, Zhang SN. The tectonic-sedimentary system of the Dainan Formation in Majiazui-Lianmenzhuang region, Gaoyou Sag. Pet Geol Oilfield Dev Daqing. 2007;26(1):13-7 (in Chinese).

Zhang XL, Zhu XM, Zhong DK, et al. Study on sedimentary facies and their correlations with subtle traps of the Dainan Formation, Paleogene in Gaoyou Sag, Subei Basin. J Palaeogeogr. 2005;7(2):207-18 (in Chinese).

Zhao DN, Zhu XM, Liang B, et al. Seismic sedimentology of the Palaeogene Dainan Formation in the deep sag zone of Gaoyou Depression, Jiangsu Province. Geol J Chin Univ. 2015;21(2):336-45 (in Chinese).

Zhao XZ, Jin FM, Wang Q, et al. Hydrocarbon accumulation principles in troughs within faulted depressions and their significance in exploration. Pet Sci. 2011;8:1-10.

Zhou J, Lin CM, Li YL, et al. Provenance analysis of Dainan Formation (Paleogene) of Majiazui in Gaoyou Sag, Subei Basin. Acta Sedimentol Sin. 2010;28(6):1117-28 (in Chinese).

Zhou SX, Wright VP, Platt NH, et al. Lacustrine sedimentary systems and hydrocarbon. Beijing: Science Press; 1991. p. 203 (in Chinese).

Zhu G, Jiang QQ, Piao XF, et al. Role of basement faults in faulting system development of a rift basin: an example from the Gaoyou Depression in southern Subei Basin. Acta Geol Sin. 2013;87(4):441-52 (in Chinese). 